\title{
THE CONTENT AND ROLE OF INTRINSIC MOTIVATION IN CREATIVE WORK: THE IMPORTANCE OF SEEKING "ENJOYMENT"
}

\author{
Chairin $\mathrm{AN}^{*}$ \\ Kyungnam University, College of Liberal Arts, Department of Cultural Content 7, \\ Gyeongnamdaehak-ro, Masanhappo-gu, Changwon-si, Gyeongsangnam-do, South Korea, 51767
}

Received 8 November 2018; accepted 13 June 2019

\begin{abstract}
The present paper assesses the "content" and "role" of intrinsic motivation during the creative production process. Based on semi-structured interviews with 16 light-entertainment television producers-directors in South Korea, it was observed that intrinsic motivation towards creative work included a desire to maintain enjoyment from such activities. Enjoyment was classified into two types: enjoyment based on job expectations and enjoyment based on the actualization of individual creative ambitions. Additionally, intrinsic motivation tended to provide a strong buffer against unfavourable working conditions that resulted from market principles (viewership ratings), economic stability, and work-life balance. Overall, the present results suggest that creative workers' tendencies to endure various undesirable working conditions are based on a strong intrinsic motivation to maintain enjoyment from their career.
\end{abstract}

Keywords: creative labour, creative production, enjoyment, intrinsic motivation, process, producer-director.

\section{Introduction}

It has been widely agreed upon that creative labourers (CLs) express high levels of satisfaction with their job, even when working conditions and wages are less than ideal (Arvidsson, Malossi, \& Naro, 2010; Hesmondhalgh \& Baker, 2011). Much research suggests that this tendency is based on CLs' intrinsic motivation (IM). In other words, a majority of CLs appreciate the ability to express themselves, which can lead to work-oriented IM (Gill, 2002; Ross, 2003; Stahl, 2005; Christopherson, 2008; Arvidsson et al., 2010).

In the studies of the creative industries, IM has been understood as the indispensable ground that could explain the creative workers' (CWs') will to continue their job, as the level of external rewards is too low and unstable (Bilton \& Leary, 2002; Storr, 1972). Additionally, after Teresa Amabile's (1998) pessimistic view towards the effect of "extrinsic" motivation has been

${ }^{\star}$ Corresponding author. E-mail: pumangze@kyungnam.ac.kr 
widely accepted, which viewed that physical rewards or penalty is inappropriate to encourage CWs, it has been easily assumed that the best management for creative process (CPR) is to separate creatives from "suits" and to provide a great level of autonomy as much as possible. However, as Amabile emphasised, "strategic targets" could enhance the level of creativity in an organisation, which could intervene the CPRs (Bilton \& Leary, 2002, p. 58). Thus, in general, it has been widely believed that managers need to set up the clear aim of a creative project, but at the same time, they need to ensure the enough level of autonomy in CPR.

Business and management scholars have regarded IM as a key factor for reinforcing creative competence (CC) within an organization. In particular, studies in the field of business administration addressing theories of creativity, creative management, and creative organizations tend to focus on how to enhance IM in order to simultaneously improve efficiency and creativity within corporate activities (Bilton \& Cummings, 2010; Sawyer, 2012; Amabile, 1996).

Based on these two approaches, the role of "IM" among CWs can be divided into two categories: a foundation by which CLs endure dire working conditions and a catalyst to help workers express themselves through labour activities. Discourses regarding creative labour (CLA) in traditional cultural studies, rooted in sociological perspectives, generally interpret IM as the first role (i.e., a mechanism) by which CLs endure unfavourable working conditions. However, past research has been inadequate in determining whether CWs actually embody such motivation, what type of IM is present, and/or how such motivation is experienced or compromised.

In a similar vein, while the statement, "CLs have a strong IM" has been considered a given, little work has examined how IM is structured and whether IM actually plays a key role in determining a worker's quality of life. Without addressing such issues, it will be difficult to understand choices made by many CLs who sustain their work, even after experiencing poor labour conditions.

By drawing upon the previous studies on cultural studies of CLA, the present study sets out to answer to the following research questions: 1) What is the "content" of IM? 2) What "roles" are given to IM?

The "content" refers to the type of IM one applies while the "role" refers to how IM influences the thoughts and behaviours that are expressed. Based on this, the paper closely examines the content of IM from the viewpoint of CLs, with a focus on the role IM plays in creative production (CP). To this end, studies will be reviewed first to assess how IM in creative work (CWO) contexts has been discussed and then describe how the content and role of IM is experienced by CLs through in-depth interviews. Participants included television producers-directors (PDs) in South Korea. The role of IM on the CPR was investigated through three different topics: audience, financial stability, and work-life balance.

\section{Literature review}

CLA, through the expression of individual creativity, includes work that typically generates the highest possibility range of intrinsic rewards (IRs). It is believed that CLs tend to have more pleasure, satisfaction, enjoyment, and self-esteem due to a passion for their work (Hesmondhalgh \& Baker, 2011; Florida, 2012; Ursell, 2006). Previous studies on IM among CLs 
have assumed that as creative labourers have an extremely high desire to express themselves and reveal their personal creative world through the process of $\mathrm{CP}$, they have strong IM for creative work itself (McRobbie, 2016; Arvidsson et al., 2010; Christopherson, 2008; Stahl, 2005; Ross, 2003; Gill, 2002). In this context, the "content" of IM can be understood as a desire (of labourers) to express themselves and reveal their personal creative world, and the role is to enhance autonomy about the work, itself. In general, strong IM for one's work will often spur individuals to work harder and more diligently (Deci \& Ryan, 1985).

Previous research on the "content" of IM among CLs can be divided into two categories. The first concerns the superficial attraction of the cultural and creative industry. Gillian Ursell (2006) stated that people tend to be attracted by the glamour - as seen from the outside - of the media industry. This is closer to the argument that IM is not formed autonomously but is rather based on outside perceptions. This interpretation, often seen in cultural studies from post-Foucauldian researchers, presumes that CLs' work autonomy is "false", and these individuals have just been "seduced" by the image of autonomy (Banks, 2007; Ross, 2003; Stahl, 2005; Ursell, 2006; Knights \& McCabe, 2003; McRobbie, 2002; Nixon, 2003; Prichard, 2002).

The second perspective defines content as the desire to implement (one's) own creative world and realize ambitions. As the realization of creative ambition (CA) is a core part of the $\mathrm{CP}$ process, creators want to project personal preferences and tastes onto this process. From a similar point of view, Nando Malmelin and Sari Virta (2016) observed that media experts are strongly motivated by the opportunity to create products, and journalists are motivated by the mere opportunity to create. This approach has led to considerations regarding how to best manage organisations and improve IM among CLs (Amabile, 1996, 1998; Amabile \& Kramer, 2011; Rosso, 2014).

This second approach is closely related to IM's "role" in the CP process. Here, CLs could be passionate about their work, even in a difficult situation. This is in line with the "labour of identity", which is a tendency shared by most CLs. CLs tend to maintain their identity as a "creative individual", as well as a labourer, and this encourages CLs to preserve their identity, even in a less than ideal environment (Cnossen, Loots, Witteloostuijn, van A, forthcoming; Pratt, Rockmann, \& Kaufmann, 2006; Alvesson, Lee Ashcraft, \& Thomas, 2008; Wei, 2012; An, 2016). In short, it is safe to say that this form of IM plays a role in encouraging labourers to create high-quality symbolic products in spite of any dire working conditions.

The "content" and "role" of CLs' IM are assessed through highly subjective standards and can be easily compromised through a complicated network of interests and various environmental factors (Hesmondhalgh \& Baker, 2011). This can result in voluntary "long-hours" or "overtime labour", which could ultimately lead to self-exploitation. Hence, there is a risk that high levels of IM can implicitly lead CWs to endure poor working conditions (Arvidsson et al., 2010; Christopherson, 2008; Gill \& Pratt, 2008; Stahl, 2005).

Much research in the area of cultural labour tends to focus on CLA markets in the periphery, rather than mainstream CLA industries. Also, past research has mostly dealt with the working environment and realities of a younger generation of workers newly entering the labour market (LM) (e.g., Arvidsson et al., 2010; Christopherson, 2008; Gill, 2002; Ross, 2003; Stahl, 2005). 
In any industry, newcomers are less likely to be given core tasks and are rather allocated repetitive work in less than ideal working conditions. CLA is not an exception. Previous studies - based on case studies of relatively young workers who newly entered the creative industry - mostly focus on revealing hidden aspects of the cultural and creative industry, which is actually less attractive than it may look (Stahl, 2005; Ross, 2003; Gill, 2002; Ursell, 2006). Researchers have been more than willing to reveal that CLs may seem to be enjoying a glamorous life when, in fact, they are suffering from overwork and an extremely low quality of life. Against this backdrop, CWs' IM has been understood as a driving force that helps workers endure these harsh realities (Ross, 2003; Stahl, 2005) or a mechanism to lure CLs through the prospect of self-realization through work, a dream that may never be realized (Ursell, 2006; Ross, 2003; Stahl, 2005; Knights \& McCabe, 2003; McRobbie, 2002; Nixon, 2003; Prichard, 2002).

In sum, little work has examined the reality of IM for CWO through CLs' perspectives or has clearly examined at what point during the CPR IM wields an influence. Thus, the present paper investigated the "content" and "role" of CLs' IM from interviews with middle-grade light-entertainment television (LETV) PD(s) in South Korea.

\section{Research methodology}

The basic design of the current study follows qualitative research, which prefers interpretation of lived experiences and aims to generate a theory based on such empirical investigation. To this end, I adopted semi-structured in-depth interviews as the primary method for this study as this enabled face-to-face interactions and mutual communication with those able to share their lived-experiences of CWO. To analyse the interview data, thematic analysis was carefully chosen as the primary research method. Unlike other widely used qualitative analytic methods (such as discourse analysis, grounded theory, and narrative analysis), thematic analysis allows for a high level of flexibility in using a range of theoretical approaches (Braun \& Clarke, 2006). Since the current research examines a variety of theories from cultural studies, creativity studies, and management/organisation research with regard to the issues of CWO, IM and autonomy during the CP process, such flexibility was considered advantageous. Among two types of thematic analysis (inductive and theoretical), for the purpose of this study, which primarily seeks to articulate the lived experiences of PDs in the CP process, inductive analysis was considered the most appropriate to observe the specificity of CLA.

For interviews, experienced CLs, who were established in the cultural industry, were selected as participants. Participants were chosen among main PDs that led the production of LETV programs. A total of 16 main PDs were interviewed, and the sample had an average work experience of 14.3 years at the time of the interview. To reflect various employment types and hierarchies between broadcasting stations unique to the industry, researchers met PDs from both terrestrial and cable television companies. PDs with various employment statuses - regular, irregular, and free-lance workers - were interviewed (see Table 1). 
Table 1. Interviewee list (source: created by author)

\begin{tabular}{|c|c|c|c|c|}
\hline$\#$ & Interviewee & Gender & $\begin{array}{l}\text { Career length } \\
\text { (years) }\end{array}$ & Organisation type \\
\hline 1 & WL & M & 16 & Cable (entertainment) \\
\hline 2 & HS & $\mathrm{F}$ & 14 & Cable (entertainment) \\
\hline 3 & $\mathrm{HJ}$ & M & 9 & Cable (manifold) \\
\hline 4 & EK & $\mathrm{F}$ & 13 & Cable (manifold) \\
\hline 5 & SL & $M$ & 8 & Cable (entertainment) \\
\hline 6 & $\mathrm{JP}$ & $\mathrm{M}$ & 13 & Cable (entertainment) \\
\hline 7 & SP & $\mathrm{M}$ & 24 & Cable (entertainment) \\
\hline 8 & $\mathrm{EH}$ & $\mathrm{M}$ & 15 & Cable (manifold) \\
\hline 9 & YP & $M$ & 14 & Cable (manifold) \\
\hline 10 & $\mathrm{JL}$ & $\mathrm{F}$ & 14 & Cable (manifold) \\
\hline 11 & OJ & $\mathrm{M}$ & 15 & Freelance \\
\hline 12 & $\mathrm{BM}$ & $M$ & 10 & Cable (manifold) \\
\hline 13 & TM & $\mathrm{M}$ & 11 & Cable (entertainment) \\
\hline 14 & $\mathrm{JJ}$ & $\mathrm{M}$ & 30 & Terrestrial \\
\hline 15 & YJ & $\mathrm{F}$ & 9 & Cable (entertainment) \\
\hline 16 & HWS & M & 15 & Cable (entertainment) \\
\hline
\end{tabular}

This study focused more on "the reasons why CLs maintain their jobs", not as a "driving force for enduring harsh realities" of "IM" for CP. This is because main PDs likely have a reputation in the LM and are enjoying substantial autonomy and responsibility.

When undertaking thematic analysis of the interview data, NVivo 10 was mainly used. Following the general process of thematic analysis, the main theme of the current paper was decided. The main theme embraces the issues of individual CAs, an individual's desire to have a higher level of creative freedom, and how an individual balances this with other desires for economic stability.

\section{Intrinsic motivation: seeking "enjoyment" from work}

During the interview, respondents used the word "enjoyment" repetitively when describing their work. In particular, the majority pointed out enjoyment as the most important factor for maintaining a career. This tendency raised the need for further examination as to the substantive meaning of enjoyment and its influence. Here, enjoyment reflected IM sought through work, which was closely associated with key issues, including quality of life, worklife balance, wages, family, and work hours. Respondents reported high levels of autonomy and activities toward the paradoxical problems associated with seeking enjoyment. The PDs also displayed a strong tendency to emphasize personal criteria when prioritizing their own "values". Here, desires for appropriate economic rewards or quality of life were not entirely excluded during the process of seeking enjoyment (IM) through work. 


\subsection{The content of intrinsic motivation}

\subsection{1. "Enjoyment" based on outside views}

As for the primary factors underlying enjoyment as an assistant director, who just entered the $\mathrm{LM}$, respondents mentioned general views on the broadcasting industry from an outsider's perspective (e.g., the job is glamorous and attractive): "being a member of a famous broadcasting company" (respondent EH), "meeting with famous people frequently" (JJ, SL), "seeing everybody talking about the program I work on the next day" (SP). However, respondents mentioned that such enjoyment, which was related to expectations and aspirations the PDs had about the industry before entering the market, tends to fade over time. By the time aspects that were perceived as "amazing" at first become normal, enjoyment based on outside perspectives is no longer sufficient.

Several cultural studies have observed that the media industry "seduces" workers who are beguiled by the glamour of the industry and are susceptible to enduring poor working conditions later (Ross, 2003; Stahl, 2005; Ursell, 2006; Knights \& McCabe, 2003; McRobbie, 2002; Nixon, 2003; Prichard, 2002). However, factors underlying enjoyment, as reported by CLs, are not that one-dimensional. Although the majority of respondents admit that they had some "fantasy" regarding the broadcasting industry when starting their career, secondary enjoyment evolves when that fantasy fades. From here, workers create symbolic products and receive recognition for their labour and enjoy communicating these products with others.

\subsubsection{Experience of subjective "enjoyment" as a creative producer}

Compared to simple expectations or aspirations formed before entering the LM, enjoyment from the process of producing and being recognized for a creative product (CPRO) can be regarded as subjective enjoyment. The majority of respondents stated that they enjoy the production process, itself, which reflects PDs' own creative world or personal standards for excellence. This enjoyment is instrumental in maintaining their jobs. Also, this enjoyment propels PDs into doing the best they can to obtain the maximum level of autonomy in their work. As a result, enjoyment becomes a driving force for facilitating hard work with the goal of creating the best possible output.

\subsection{The role of intrinsic motivation}

\section{2. 1. Pressure of viewership ratings versus realization of creative desire}

ETV PDs are tasked with producing commercial programming and are never free from the pressure of viewership ratings. However, PDs have to go beyond the standard market formula and present something new, which is only possible when they can find values others have not revealed. This process is mainly driven by IM to use one's CC to find "novelty" and "values" for something important. Under the pressure for making programs with high viewer ratings, one of the biggest motivators for PDs is to stick to one's personal standards for excellence, tastes, and preferences.

Most respondents were fully aware that it is difficult to obtain an ideal level of creative autonomy (CAU) in the current working environment. However, what these PDs have in 
common is a desire to try hard in order to achieve maximum autonomy, even if it means going through a complicated negotiation process among various stakeholders. Furthermore, many respondents stated that they enjoy this negotiation process, which moderates the level of CA between the needs of viewers and requirements of the broadcasting company (respondents WL, JL, SL, HJ, BM). Also, the majority of respondents agreed that the job of a PD is hard to maintain unless one is able to have fun with the work.

These findings could be pessimistically interpreted as the PDs being forced to endure difficult working conditions and "seduced" by the false promise that PDs can fulfil their CA when in fact it will never happen within a commercialist broadcasting environment. However, unlike the concerns of previous cultural and labour studies, the PDs interviewed revealed a relatively realistic approach to seeking CAs with the reality of having to produce commercial programs. In essence, the PDs had a reasonable, if not ideal, way of thinking about "economic stability" and "work-life balance", which will be discussed later.

\subsubsection{Economic stability versus sustainability of "enjoyment"}

Most respondents stated that wages for PDs are not commensurate with the amount of labour engaged. For instance, PDs mentioned long working-hours without a fixed time for coming into (and leaving) work, as it is practically impossible to ask for overtime pay for extra hours and holidays. However, whenever extrinsic awards were mentioned, PDs showed a strong tendency toward emphasizing IRs of their job.

Respondent SL says:

"It is true we are not paid as much as we work. The company probably goes bankrupt
if it pays PDs all the overtime and holiday work allowances (laugh). To be sure, it's a
problem from the perspective of working hours. I don't have personal time, and the
job is gruelling. But I still do it because I enjoy what I'm doing. This enjoyment is ir-
replaceable. One thing I'm sure about is that my job is especially rewarding compared
to other occupations".

For the majority of respondents, the biggest reason for wanting to maintain or upgrade their current financial status was to sustain IM for the work. This is not to say that respondents gave up any extrinsic rewards for the intrinsic; instead, this was a process of seeking extrinsic rewards in order to maintain intrinsic benefits of the work.

When talking about copyright issues, respondents were ambivalent as to specific royalties and IMs for the CPR. PDs working for an organisation tend to regard royalties not as a financial reward but something close to an IR, which is associated with the honour or official recognition of their CC. This is in line with the general trend of cultural creators wanting to project their identity onto the CPRO (McRobbie, 2002; Lee, 2012; Elsbach, 2009; Hesmondhalgh \& Baker, 2011; An, 2016).

The majority of respondents were less than willing to give up a stable organisational and economic base (extrinsic motivation) for receiving royalties, which is also akin to an IR. Unlike other areas, broadcast productions cannot be completed solely through individual effort. A well-equipped working environment with an organisational system is crucial for producing quality programming. In particular, maintaining a career as an ETV PD is nearly impossible without belonging to a stable broadcasting company in South Korea. Furthermore, economic 
stability as a wage earner for an established organisation is a favourable condition for maintaining a career.

In this respect, the tendency of respondents to stay with an organisation whereby stable payment is guaranteed, even if it is difficult to claim royalties, is understood as a willingness to maintain a creative identity and sustain enjoyment from the CPR. In short, financial stability allows labourers to maintain IM for their creative endeavours.

\subsubsection{Work-life balance versus maintaining a creative job}

Most respondents were not aware of any significant issues regarding "work-life balance". Instead, respondents seemed to seek understanding from others regarding PDs' unique job situations. For instance, respondent JP described himself as "selfish" because he tries to maintain his job although his family does not like it:

"Honestly, I'm doing my job entirely for myself. I know; I'm a bit selfish. My wife doesn't like my job because I have no time to be with the kids. But there are not many jobs out there where I can make money for doing what I enjoy this much. Not that I'm interested in starting my own business or sales $<\ldots>$.

Overall, the PDs agreed that job-related activities take up a big part of one's life and that a choice is made to maintain enjoyment from work. This type of response could be dismissed as mere personal thoughts of a few or criticized as a tendency to showcase one's own job/ life to appear more ideal than the reality. However, as a former television PD, the author can speak to the veracity of these responses and that other PDs with similar programming experience (e.g., those not interviewed for this study) have similar sentiments. Thus, assessing work life quality from the outside is not sufficient for understanding CLs' tendencies to seek IM and rewards.

\section{Conclusions and implications}

It would be premature to argue against previous research trends regarding IM among CLs based on a single case study. However, the present interviews highlight that PDs' IM for the $\mathrm{CP}$ process, and desire for IRs, appears to be formed autonomously and actively and not from the external environment. Additionally, PDs' intrinsic work motivation is not a detrimental factor to one's quality of life but plays a role in maintaining harmony (i.e., between economic stability, work-life balance, and relationships with others).

The present findings suggest that a multi-faceted approach for assessing CLA, and its peculiarities when compared to general labour, is needed. If CLs are just enduring difficulties based on the superficial appeal of CLA, it is hard to justify why these individuals are staying employed for so long while maintaining enjoyment in the CP process.

The present study examined evidence for the autonomous and active formation of IM among CLs who seek satisfaction and joy based on personal ambitions through work, not as helpless individuals deprived of CAU under commercial pressures. To be sure (as concerns have been voiced), IRs were still assessed subjectively and could easily be compromised by an individual's surroundings. Nevertheless, it should be possible to establish a cultural production system that reflects the unique characteristics of CLA based on the following: CLs 
think highly of maintaining work enjoyment throughout their career, and IM plays a pivotal role in the CP process. If the biggest driving force behind CLs' competence is maintaining "enjoyment from work", we should examine what organisations and society could do to help these individuals in this regard. This should lead to discussions regarding the necessity of institutions that support economic stability for CLs, as well as organisational strategies that specifically reflect the CP process. This all starts with embracing CLs as active agents of society and giving more weight to the value these individuals place on enjoying their work.

\section{References}

Alvesson, M., Lee Ashcraft, K., \& Thomas, R. (2008). Identity matters: reflections on the construction of identity scholarship in organization studies. Organization, 15(1), 5-28. https://doi.org/10.1177/1350508407084426

Amabile, T. M. (1996). Creativity in context: update to the social psychology of creativity. New York: Routledge.

Amabile, T. M. (1998). How to kill creativity. Harvard Business Review, 76(5), 77-87.

Amabile, T., \& Kramer, S. (2011). The progress principle: using small wins to ignite joy, engagement, and creativity at work. Boston, Massachusetts: Harvard Business Review Press.

An, C. (2016). The multiple identities of creative labourers and negotiated creative autonomy: an empirical research with light-entertainment television PDs in South Korea (PhD Thesis). University of Warwick, Coventry, England [unpublished source].

Arvidsson, A., Malossi, G., \& Naro, S. (2010). Passionate work? Labour conditions in the Milan fashion industry. Journal for Cultural Research, 14(3), 295-309. https://doi.org/10.1080/14797581003791503

Banks, M. (Ed.). (2007). The politics of cultural work. New York: Palgrave Macmillan. https://doi.org/10.1057/9780230288713

Bilton, C., \& Cummings, S. (2010). Creative strategy: reconnecting business and innovation. West Sussex: John Wiley \& Sons Ltd.

Bilton, Ch., \& Leary, R. (2002). What can managers do for creativity? Brokering creativity in the creative industries. International Journal of Cultural Policy, 8(1), 49-64. https://doi.org/10.1080/10286630290032431

Braun, V., \& Clarke, V. (2006). Using thematic analysis in psychology. Qualitative Research in Psychology, 3(2), 77-101. https://doi.org/10.1191/1478088706qp063oa

Christopherson, S. (2008). Beyond the self-expressive creative worker: an industry perspective on entertainment media. Theory, Culture \& Society, 25(7-8), 73-95. https://doi.org/10.1177/0263276408097797

Cnossen, B., Loots, E., \& Witteloostuijn, van A. (Forthcoming). Individual motivation among entrepreneurs in the creative and cultural industries: a self-determination perspective. Creativity and Innovation Management, 28(3), 389-4-2. https://doi.org/10.1111/caim.12315

Deci, E. L., \& Ryan, R. M. (1985). Intrinsic motivation and self-determination in human behavior. In E. Aronson (Ed.). Series: Perspectives in Social Psychology. New York and London: Plenum Press. https://doi.org/10.1007/978-1-4899-2271-7

Elsbach, K. D. (2009). Identity affirmation through "signature style": A study of toy car designers. Human Relations, 62(7), 1041-1072. https://doi.org/10.1177/0018726709335538

Florida, R. (2012). The rise of the creative class (Revisited). New York: Basic Books.

Gill, R. (2002). Cool, creative and egalitarian? Exploring gender in project-based new media work in Euro. Information, Communication \& Society, 5(1), 70-89. https://doi.org/10.1080/13691180110117668 
Gill, R., \& Pratt, A. C. (2008). In the social factory? Immaterial labour, precariousness and cultural work. Theory, Culture \& Society, 25(7-8), 1-30. https://doi.org/10.1177/0263276408097794

Hesmondhalgh, D., \& Baker, S. (2011). Creative labour: media work in three cultural industries. Series: Culture, Economy and the Social. London and New York: Routledge.

Knights, D., \& McCabe, D. (2003). Governing through teamwork: reconstituting subjectivity in a call centre. Journal of Management Studies, 40(7), 1587-1619. https://doi.org/10.1111/1467-6486.00393

Lee, D. (2012). Precarious creativity: changing attitudes towards craft and creativity in the british independent television production sector. Creative Industries Journal, 4(2), 155-170. https://doi.org/10.1386/cij.4.2.155_1

Malmelin, N., \& Virta, S. (2016). Managing creativity in change. Journalism Practice, 10(8), 1041-1054. https://doi.org/10.1080/17512786.2015.1074864

McRobbie, A. (2016). Be creative. Cambridge, Malden, MA: Polity Press.

McRobbie, A. (2002). Clubs to companies: notes on the decline of political culture in speeded up creative worlds. Cultural Studies, 16(4), 516-531. https://doi.org/10.1080/09502380210139098

Nixon, S. (2003). Advertising cultures: gender, commerce, creativity. Series: Culture, Representation and Identities. London: SAGE Publications. https://doi.org/10.4135/9781446218839

Pratt, M. G., Rockmann, K. W., \& Kaufmann, J. B. (2006). Constructing professional identity: the role of work and identity learning cycles in the customization of identity among medical residents. The Academy of Management Journal, 49(2), 235-262. https://doi.org/10.5465/amj.2006.20786060

Prichard, C. (2002). Creative selves? Critically reading "creativity" in management discourse. Creativity and Innovation Management, 11(4), 265-276. https://doi.org/10.1111/1467-8691.00258

Ross, A. (2003). No-Collar: the humane workplace and its hidden costs. New York: Basic Books.

Rosso, B. D. (2014). Creativity and constraints: exploring the role of constraints in the creative processes of research and development teams. Organization Studies, 35(4), 551-585. https://doi.org/10.1177/0170840613517600

Sawyer, R. K. (2012). Explaining creativity: the science of human innovation. Oxford: Oxford: New York: Oxford University Press, Inc.

Stahl, M. (2005). Nonproprietary authorship and the uses of autonomy: artistic labor in American film animation, 1900-2004. Labor: Studies in Working-Class History, 2(4), 87-105. https://doi.org/10.1215/15476715-2-4-87

Storr, A. (1972). The dynamics of creation. New York: Ballantine Books.

Ursell, G. (2006). Working in the media. In D. Hesmondhalgh (Ed.), Media production, 3, 134-171. Berkshire: Open University Press.

Wei, J. (2012). Dealing with reality: market demands, artistic integrity, and identity work in reality television production. Poetics, 40(5), 444-466. https://doi.org/10.1016/j.poetic.2012.07.002

\title{
VIDINĖS MOTYVACIJOS KŪRYBINIAME DARBE TURINYS IR VAIDMUO: „PASITENKINIMO“ PAIEŠKŲ SVARBA
}

\author{
Chairin An
}

\section{Santrauka}

Šiame straipsnyje ịvertinamas vidinès motyvacijos „turinys“ ir „vaidmuo“ gaminant kūrybinę produkciją. Remiantis pusiau struktūruotais interviu su 16 lengvo turinio pramogines laidas transliuojančios Pietų Korèjos televizijos prodiuseriais ir 
režisieriais, buvo nustatyta, kad vidinė kūrybinio darbo motyvacija - tai troškimas nuolat išlaikyti tokios veiklos teikiamą pasitenkinimą. Pasitenkinimas buvo suklasifikuotas ị du tipus: pasitenkinimas, grindžiamas darbo lūkesčiais, ir pasitenkinimas, paremtas individualių kūrybos ambicijų realizavimu. Be to, dèl vidinès motyvacijos esama tendencijos gerokai pozityviau vertinti nepalankias darbo sąlygas, susiklosčiusias vyraujant rinkos principams (žiūrovų reitingai), ekonominiam stabilumui bei profesinio ir asmeninio gyvenimo pusiausvyrai. Apskritai šie rezultatai rodo, kad kūrybinių darbuotojų tendencijas ištverti ̨̣vairias netinkamas darbo sąlygas grindžia stipri vidinè motyvacija nuolat išlaikyti pasitenkinimą, kurị jiems teikia karjera.

Reikšminiai žodžiai: kūrybinis darbas, kūrybinè produkcija, pasitenkinimas, vidinė motyvacija, procesas, prodiuseris ir režisierius. 